\title{
EVALUACIÓN HIDROGEOLÓGICA DEL ACUÍFERO PARRITA, PACIFICO CENTRAL DE COSTA RICA
}

\author{
Rafael Matamoros (2010)
}

Se realizó una evaluación hidrogeológica del acuífero en el sector de Parrita, provincia de Puntarenas, con el fin de generar herramientas técnicas para la planificación y toma de decisiones. La zona de Parrita corresponde con una de las regiones costeras con mayor crecimiento demográfico y económico del país, lo que podría provocar que la demanda del recurso hídrico se vea en aumento, debido a la necesidad de satisfacer las necesidades de su población.

Para el estudio, se llevó a cabo consulta bibliográfica y recolección de datos en campo, mediante pruebas de infiltración, pruebas de bombeo y monitoreo de niveles en pozos, sondeos eléctricos verticales, inventario de pozos y nacientes sin concesión, muestreo de suelos y aguas para análisis físico-químicos e isótopos de deuterio y oxígeno-18. Con los datos recolectados, se construyó perfiles hidrogeológicos y geoeléctricos, balances hídricos de suelos para el cálculo de recarga potencial, se utilizó el método de balance de aguas subterráneas para obtener un aproximado del volumen disponible de agua, diagramas hidrogeoquímicos para la caracterización del agua, análisis de isotopía en relación al sistema hídrico, y se generó mapas temáticos para diferentes componentes del modelo conceptual hidrogeológico y mapas productos de recarga potencial y vulnerabilidad intrínseca.

El acuífero presenta una extensión de 133,49 $\mathrm{km}^{2}$, está constituido de limos, arcillas, arenas y gravas, su espesor varía entre 5 a $25 \mathrm{~m}$ aproximadamente, los niveles de agua subterránea presentan profundidades entre 0 y $10 \mathrm{~m}$ aproximadamente, la dirección del flujo subterráneo es hacia el sur y presenta alta influencia de la tectónica. El techo del acuífero se compone de limos y arcillas, con espesores entre 2-21 m, otras áreas se componen de finos hasta gravas, los cambios de granulometría del techo del acuífero crean variaciones en el grado de confinamiento hidráulico. La recarga potencial es de 6292,85 $\mathrm{mm} / \mathrm{año}$. El acuífero se encuentra subexplotado, pues el volumen de la recarga potencial $(4229,88$ $1 / \mathrm{s}$ ) es mucho mayor que el volumen de las descargas $(657,601 / \mathrm{s})$. Desde el punto de vista hidrogeoquímico e isotópico, las aguas son bicarbonatadas-cálcicas, con una recarga inmediata, tanto directa como lateral hacia el acuífero. El acuífero presenta cuatro zonas de vulnerabilidad intrínseca a la contaminación: Baja, Media, Alta y Extrema. 